\title{
Expiration-Day Effects on Index Futures: Evidence from Indian Market
}

\author{
Ravi Kumar SAMINENI ${ }^{1}$, Raja Babu PUPPALA ${ }^{2}$, Ramesh MUTHANGI ${ }^{3}$, Syamsundar KULAPATHI ${ }^{4}$ \\ Received: August 01, 2020 Revised: September 28, 2020 Accepted: October 05, 2020
}

\begin{abstract}
Nifty Bank Index has started trading in futures and options (F\&O) segment from $13^{\text {th }}$ June 2005 in National Stock Exchange. The purpose of the study is to enhance the literature by examining expiration effect on the price volatility and price reversal of Underlying Index in India. Historical data used for the current study primarily comprise of daily close prices of Nifty Bank which is the only equity sectoral index in India which is traded in derivatives market and its Future contract value is derived from the underlying CNX Bank Index during the period $1^{\text {st }}$ January 2010 till $31^{\text {st }}$ March 2020. To check stationarity of the data, Augmented Dicky Fuller test was used. The study employed ARMA- EGARCH model for analysing the data. The empirical results revealed that there is no effect on the mean returns of underlying Index and EGARCH $(1,1)$ model furthermore shows there is existence of leverage effect in the Bank Index i.e., negative shocks causes more fluctuations in the Index than positive news of similar magnitude. The outcome of the study specifies that there is no effect on volatility on the underlying sectoral index due to expiration days and also observed no price reversal effect once the expiration days are over.
\end{abstract}

Keywords: CNX Bank Index, Nifty Bank Index, Expiration Day, Price Reversal, Volatility

JEL Classification Code: C22, G10, G12, G13

\section{Introduction}

Indices traded in derivatives segment in National Stock Exchange (NSE) are Nifty Futures and Nifty Bank Futures. Nifty is an index which embodies 50 utmost liquid and large cap stocks from the NSE. On the other side, Bank Nifty has banking stocks recorded under it. Nifty has stocks from diversified sectors like banks, automobiles, and pharma etc., registered under it. Bank Nifty is a sectoral index with emphasis only on the banking stocks which includes both private and PSU banks. Nifty Bank is now one of the main

${ }^{1}$ First Author and Corresponding Author. Research Scholar, Department of Management Studies, K L Deemed to be University, Andhra Pradesh, India [Postal Address: H. No: 6-626/1, Vimanapuri Colony, Near Government School, Quthbullapur, Telengana-500055, India] Email: samineni08@gmail.com

${ }^{2}$ Associate Professor, Department of Management Studies, K L Deemed to be University, Andhra Pradesh, India.

Email: dr.prb@kluniversity.in

${ }^{3}$ Research Scholar, Department of MBA, Annamalai University, Tamilnadu, India. Email: muthangiramesh@gmail.com

${ }^{4}$ Associate Professor, Department of MBA, Vignan Degree and PG College, Andhra Pradesh, India. Email: syamkulapathi@gmail.com

(c) Copyright: The Author(s)

This is an Open Access article distributed under the terms of the Creative Commons Attribution Non-Commercial License (https://creativecommons.org/licenses/by-nc/4.0/) which permits unrestricted non-commercial use, distribution, and reproduction in any medium, provided the original work is properly cited. aggressively traded index dealing with future and option contracts in derivative segment. It has gained prominence due to high weightage in the Nifty and its high correlation with the Nifty.

Bank Nifty is designed using the free float methodology where the stocks are given weightage based on the free float market capitalization. While Bank Nifty was unveiled on September 15, 2003, it considers January 01, 2000 as the reference year and 1000 as the benchmark value. Bank Nifty touched the highest value of 30,000, which shows wealth creation to the extent of 30 times over the last 17 years. The index is rebalanced twice annually while the Bank Nifty values are accessible on a real time basis throughout trading hours. Nifty Bank was the first index in NSE available for weekly options trading and presently has trading activity higher than the Nifty.

Being a sectoral index, the Nifty Bank represents only the banking sector which includes private and PSU banks. Nifty Bank consists of twelve utmost active shares from the banking industry. It offers investors and mediators a yardstick that apprehends performance of banking industry.

\section{Literature Review}

Klemkosky, (1978), Office and Trennepohl, (1981), Bhattacharya, (1987) and Pope and Yadav, (1992) observed 
adverse impact on options expiration in the return process of the common stocks. Cinar and Vu's, (1987) study on 6 different shares observed considerable positive outcome on expiration on the returns of one stock, which has negative impact on one stock and trivial impact on the remaining shares. Lewis and Day, (1988) and Chamberlain et al., (1989) observed noteworthy changes in Canada and USA at expiration of index futures and option contracts.

Stoll and Whaley (1991, 1987, \& 1990), Herbst and Maberly (1990), Hancock (1993) and Chen and Williams (1994) examined maturity effect on index futures contracts in the US markets and Karolyi's (1996) study on expiry effect on Japanese leading 225 futures contracts, observed that derivative contracts expiration led to varying trading volume in the equity market whereas the influence on price is minimal.

Kan (2001) exposed that there is absence of expiration day impact in the mean return process and turnover of ordinary stocks. Corredor et al. (2001) using Spanish data exhibited substantial effect on the turnover of common stocks, but no robust impact on asset price and variability due to maturity effect. Chow et al., (2003) observed that the effect on price and volatility on the stock market was negative, but there was no indication of abnormal trading activity on the expiry day. Alkebäck and Hagelin (2004) observed a significantly high turnover but insignificant price effect. Vipul (2005) observed noteworthy upsurge in the turnover of Indian Stock Exchange. Illueca and LaFuente (2006) observed notable higher trading volume, price and volatility effect on expiration day in the Spanish market. Fung and Yung (2009) identified high trading activity but found no considerable effect on price. Thenmozhi and Thomas (2004) found decreased underlying index volatility during expiration days than non-expiration days and could not explain the spot market volatility due to expiration-day sufficiently. Bhaumik and Bose (2007) observed that there were considerable expiration impact on volumes, day-to-day returns and volatility on Indian stock market.

Narang and Madhu (2013) reported mean returns, turnover and volatility are high not only on the expiration days but also the day after. In Mahalwala's (2016) study, the outcome was in contrast to the rest of the studies as it observed no significant effect on returns, volatility and price reversal due to expiration day. Lu and Gao's (2016) study indicated that day of week impact was substantial in Chinese Market. Wats (2017) observed that effect was not only confined to expiration day but was extended to entire expiration week. Nguyen and Nguyen (2019) observed that fluctuations in stock yields had a huge effect on futures market volatility due to shocks. Nguyen and Truong (2020) revealed that introduction of derivatives had a positive effect on trading activity of spot market.

\section{Research Methodology}

In this paper, to find maturity effect on Nifty Bank index, National Stock Exchange is selected. An index is used to gauge behavior of stock market, Nifty Bank sectoral indices is selected as proxy for measuring the behavior. Daily prices of Nifty Bank index for a period of 10 years are used for study. Last Thursday of every month is considered as the expiration day in derivatives market. If last Thursday is not operational, the previous day is considered as expiration day. In view of lopsided relation between scedastic function and mean, Nelson (1991) put forward Exponential Generalized Autoregressive Conditional Heteroskedasticity model. For finding the expiration-day effect on conditional mean, conditional variance and price reversal ARMA with EGARCH model is used for the study.

Considering dummy1 and dummy2 variables, mean and skedastic function combined with ARMA-EGARCH structure attain the shape of

Return equation with ARMA (p, q)

$$
\begin{aligned}
Y_{t}= & c \sum_{i=1}^{m} a_{i} Y_{t-i}+\sum_{j=1}^{n} b_{j} \varepsilon_{t-j}+ \\
& \lambda_{\mathrm{i}} \mathrm{DUM}_{1}+\xi_{\mathrm{i}} \mathrm{DUM}_{2}+\varepsilon_{\mathrm{t}}
\end{aligned}
$$

Variance equation with $\operatorname{EGARCH}(1,1)$

$$
\begin{aligned}
\ln \left(\mathrm{ht}_{2}\right)= & \Phi+\alpha\left|\varepsilon_{\mathrm{tt}-1} \mathrm{~h}_{\mathrm{t}-1}\right|+\gamma \varepsilon_{\mathrm{t}-1} / \mathrm{h}_{\mathrm{t}-1} \\
& +\beta \ln \left(\mathrm{h}_{2 \mathrm{t}-1}\right)+\lambda \mathrm{DUM}_{1}+\xi \mathrm{DUM}_{2}
\end{aligned}
$$

Dummy 1 represents dummy variable for expiration days where it takes value one for all expiration days and zero for remaining days. Dummy2 variable checks the effect on price reversal. Here, dummy equals to unity for immediate succeeding trading days after expiration and zero, for all trading days. The software used for analysis is E-Views.

\section{Empirical Results}

The study is designed for analysis on Nifty Bank from January 1, 2010 up to March 31, 2020, comprising of 2530 observations as depicted in Figure 1. The pictorial representation of graph of CNX Nifty Bank (Figure 1) indicates that fluctuations have appeared in bursts. First differencing tool is employed to de-trend the return series.

Figure 2 shows the mean and standard deviation are small, however, standard deviation is larger than the mean. The skewness statistic is negative, indicating distribution is asymmetric. Moreover, large excess kurtosis suggests that data is leptokurtic. The descriptive statistics discard the normality hypothesis. 
RETURN

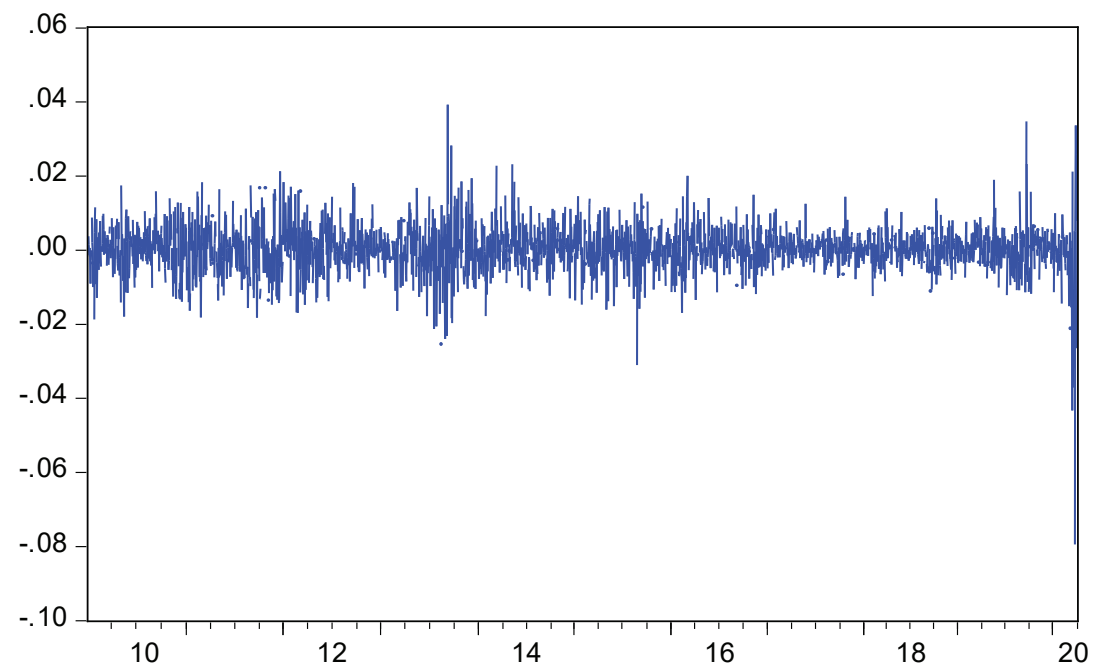

Figure 1: Line graph of Nifty Bank Return Series

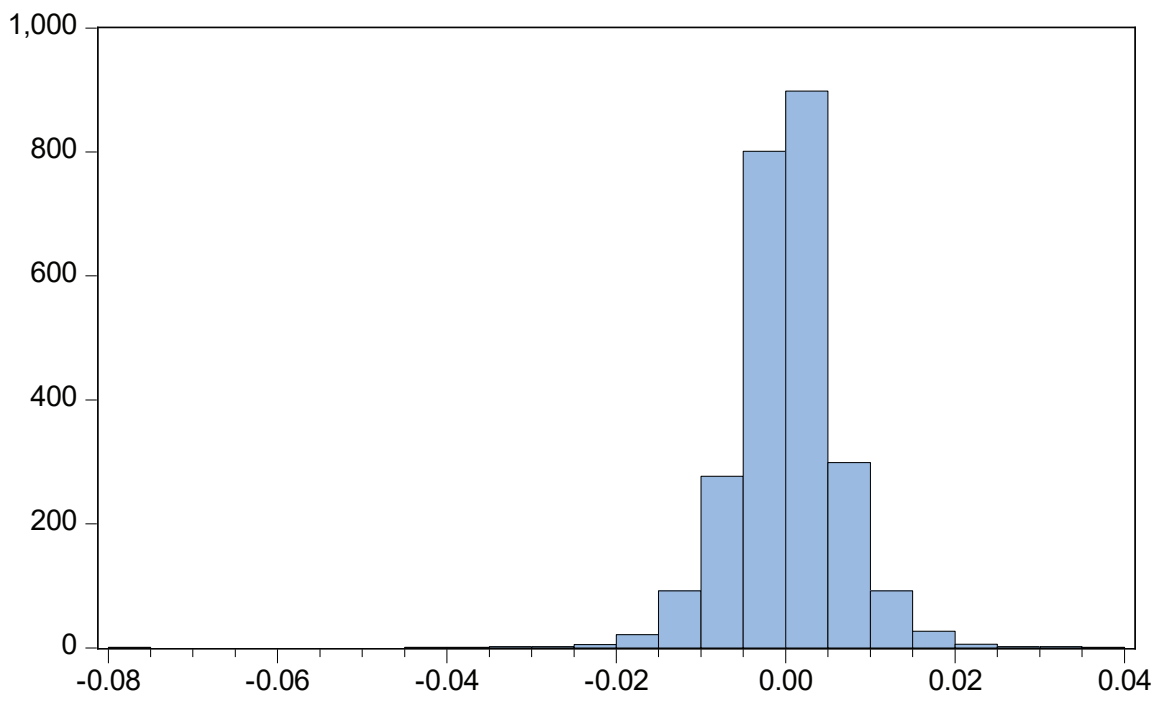

\begin{tabular}{|c|c|}
\hline \multicolumn{2}{|c|}{$\begin{array}{l}\text { Series: DLOG_PRICE } \\
\text { Sample 1/04/2010 3/31/2020 } \\
\text { Observations } 2530\end{array}$} \\
\hline Mean & 0.000127 \\
\hline Median & 0.000253 \\
\hline Maximum & 0.039248 \\
\hline Minimum & -0.079532 \\
\hline Std. Dev. & 0.006438 \\
\hline Skewness & -0.821892 \\
\hline Kurtosis & 15.55359 \\
\hline Jarque-Bera & 16897.73 \\
\hline Probability & 0.000000 \\
\hline
\end{tabular}

Figure 2: Descriptive Data of Nifty Bank

Table 1 denotes the mean return which has unit root as t-statistic (-46.38545), significant at all levels. To find out a suitable AR $(m)$ and MA $(n)$ to Bank Nifty, the study computed serial correlation and partial autocorrelation up to 20 lags as specified in Table 2. A given serial correlation function is categorized as noteworthy if the value is outside the $+/-1.99 / \sqrt{ } \mathrm{T}$ band, where $\mathrm{T}$ is total observations $(\mathrm{T}=2,530)$. Auto correlation and partial auto correlation functions both at lag 1 and 2 are outside the concurrent range (0.039).
A considerable p-value at critical 1 percent level of Q-statistic shows there is indication of auto correlation in return series for all lags considered. The outcome implies that Nifty Bank mean can be designed for ARMA method.

Schwartz Bayesian Criterion (SIC) is used to select the Autoregressive and Moving Average terms. The calculated SIC values up to lag5 are specified in Table 3 . From the structure, lowest SIC is chosen. In Table 3, ARMA $(0,1)$ shows minimum SIC value so it is appropriate for Nifty Bank return series. 
Table 1: Results of ADF Test in Nifty Bank

\begin{tabular}{|l|l|l|l|}
\hline & & t-Statistic & Prob. $^{*}$ \\
\hline Augmented Dickey-Fuller test statistic & -46.38545 & 0.0001 \\
\hline Test critical values: & $1 \%$ level & -3.432742 & \\
\hline & $5 \%$ level & -2.862483 & \\
\hline & $10 \%$ level & -2.567317 & \\
\hline
\end{tabular}

Table 2: ACFs and PACFs for the Nifty Bank

\begin{tabular}{|l|c|c|c|c|}
\hline Lag & AC & PAC & Q-Stat & Prob \\
\hline 1 & 0.080 & 0.080 & 16.183 & 0.000 \\
\hline 2 & -0.017 & -0.024 & 16.941 & 0.000 \\
\hline 3 & -0.003 & 0.000 & 16.962 & 0.001 \\
\hline 4 & 0.014 & 0.014 & 17.464 & 0.002 \\
\hline 5 & 0.024 & 0.022 & 18.925 & 0.002 \\
\hline 6 & -0.027 & -0.031 & 20.819 & 0.002 \\
\hline 7 & 0.037 & 0.043 & 24.272 & 0.001 \\
\hline 8 & -0.002 & -0.010 & 24.284 & 0.002 \\
\hline 9 & 0.036 & 0.038 & 27.526 & 0.001 \\
\hline 10 & 0.031 & 0.025 & 29.965 & 0.001 \\
\hline 11 & -0.035 & -0.038 & 33.053 & 0.001 \\
\hline 12 & 0.022 & 0.027 & 34.297 & 0.001 \\
\hline 13 & -0.021 & -0.025 & 35.450 & 0.001 \\
\hline 14 & 0.003 & 0.004 & 35.476 & 0.001 \\
\hline 15 & 0.029 & 0.031 & 37.690 & 0.001 \\
\hline 16 & 0.000 & -0.005 & 37.690 & 0.002 \\
\hline 17 & 0.003 & 0.000 & 37.715 & 0.003 \\
\hline 18 & 0.035 & 0.041 & 40.902 & 0.002 \\
\hline 19 & 0.017 & 0.003 & 41.599 & 0.002 \\
\hline 20 & -0.006 & -0.003 & 41.693 & 0.003 \\
\hline
\end{tabular}

Table 3: ARMA Framework for Mean Series using SBC

\begin{tabular}{|l|c|c|c|c|c|c|}
\hline $\mathbf{p} / \mathbf{q}$ & $\mathbf{0}$ & $\mathbf{1}$ & $\mathbf{2}$ & $\mathbf{3}$ & $\mathbf{4}$ & $\mathbf{5}$ \\
\hline 0 & -7.250462 & -7.254055 & -7.247658 & -7.247373 & -7.247567 & -7.247921 \\
\hline 1 & -7.253509 & -7.250915 & -7.250975 & -7.250418 & -7.250577 & -7.25106 \\
\hline 2 & -7.247015 & -7.250601 & -7.24429 & -7.243917 & -7.244103 & -7.244525 \\
\hline 3 & -7.246347 & -7.249926 & -7.24353 & -7.243949 & -7.243464 & -7.243818 \\
\hline 4 & -7.246168 & -7.249705 & -7.243352 & -7.24309 & -7.246174 & -7.243575 \\
\hline 5 & -7.246162 & -7.249863 & -7.243392 & -7.243066 & -7.243195 & -7.244943 \\
\hline
\end{tabular}


Table 4: Results of Maturity Effect using ARMA-EGARCH

\begin{tabular}{|l|c|c|c|c|}
\hline Variable & Coefficient & Std. Error & z-Statistic & Prob. \\
\hline C & $9.80 \mathrm{E}-05$ & 0.000118 & 0.829946 & 0.4066 \\
\hline DUMMY1 & 0.000759 & 0.000385 & 1.970702 & 0.0488 \\
\hline DUMMY2 & 0.000823 & 0.000448 & 1.836598 & 0.0663 \\
\hline MA(1) & 0.084212 & 0.020215 & 4.165821 & 0.0000 \\
\hline$C(5)$ & -0.298973 & 0.040818 & -7.324600 & 0.0000 \\
\hline$C(6)$ & 0.132670 & 0.013311 & 9.967225 & 0.0000 \\
\hline$C(7)$ & -0.082182 & 0.006734 & -12.20487 & 0.0000 \\
\hline$C(8)$ & 0.980856 & 0.003480 & 281.8895 & 0.0000 \\
\hline$C(9)$ & -0.088933 & 0.067072 & -1.325938 & 0.1849 \\
\hline$C(10)$ & 0.143874 & 0.080578 & 1.785532 & 0.0742 \\
\hline
\end{tabular}

Table 4 depicts the regression results fitted with ARMAEGARCH model for expiration-day effects. The ARCH constraints $\alpha 1(0.132670)$ and $\beta 1(0.980856)$ which are large, infer fluctuations are due to market information and variability is insistent, which will take a longer time to fade out, respectively. In the mean equation, dummy1 is notable and dummy 2 is statistically trivial with the similar sign, which means that substantial difference doesn't exist between returns during and after expiry days. It is also recognised that the price reversal is also trivial following the expirationdays. Dummy1 in variance equation with insignificant coefficient, indicates variability of Bank Nifty sectoral index and is similar on both expiration as well as on succeeding days. In variance equation dummy 2 is insignificant but with opposite sign signifying that volatility does not come back to its preceding level after expiry days.

\section{Conclusion}

The only sectoral index traded in National Stock Exchange in India is CNX Nifty Bank. The study has been conducted on CNX Nifty Bank sectoral index from January 2010 to March 2020 with 2530 observations by employing ARMA-EGARCH model. The study concluded that there is no considerable difference between the returns of Nifty Bank index on and subsequent to expiry days and the maturity effect on volatility of Nifty Bank Index is similar to succeeding day of expiration as the coefficient is insignificant. No substantial price reversal was noticed on the ensuing day of expiration i.e., the price reversal might occur on the day of expiration. From the study based on expiration day effect of sectoral index it was observed that there is no destabilization on the underlying sectoral bank index.

\section{References}

Alkebäck, P., \& Hagelin, N. (2004). Expiration day effects of index futures and options: Evidence from a market with a long settlement period. Applied Financial Economics, 14(6), 385396. https://doi.org/10.1080/09603100410001673612

Bhattacharya, A. K. (1987). Option expirations and treasury bond futures prices. The Journal of Futures Markets (19861998), 7(1), 49. https:// doi:10.1002/fut.3990070106

Bhaumik, S., \& Bose, S. (2007). Impact of derivatives trading on emerging capital markets: A note on expiration day effects in India. William Davidson Institute. Working Paper Number 863, March 2007. http://dx.doi.org/10.2139/ssrn.988175

Chamberlain, T. W., Cheung, C.S., \& Kwan, C. C. (1989), Expiration-day effects of index futures and options: Some Canadian evidence. Financial Analysts Journal, 45(5), 67-71.

Chen, C., \& Williams, J. (1994). Triple-witching hour, the change in expiration timing, and stock market reaction. Journal of Futures Markets, 14, 275-292. https://doi.org/10.1002/fut.3990140304

Chow, Y. F., Yung, H. H. M. \& Zhang, H. (2003). Expiration day effect: The case of Hong Kong. Journal of Futures Markets, 23, 67-86. https://doi.org/10.1002/fut.10054

Cinar, E. M., \& Vu, J. (1987). Evidence on the effect of option expirations on stock prices. Financial Analysts Journal, 43(1), 55-57. https://doi.org/10.2469/faj.v43.n1.55

Corredor, P., Lechon, P., \& Santamaria, R. (2001). Option-expiration effects in small markets: The Spanish stock exchange. Journal of Futures Markets: Futures, Options, and Other Derivative Products, 21(10), 905-928. https://doi.org/10.1002/fut.2002

Fung, J. K., \& Yung, H. H. (2009). Expiration-day effects: An Asian twist. Journal of Futures Markets: Futures, Options, and Other Derivative Products, 29(5), 430-450. http:// doi:10.1002/ fut.20364 
Hancock, G. D. (1993). Whatever happened to the triple witching hour?. Financial Analysts Journal, 49(3), 66-72. https://doi. org/10.2469/faj.v49.n3.66

Herbst, A. F., \& Moberly, E. D. (1990). Stock index futures, expiration day volatility, and the" special" Friday opening: A note. The Journal of Futures Markets (1986-1998), 10(3), 323. http://doi.org/10.1002/fut.3990100309

Illueca, M., \& LaFuente, J. A. (2006). New evidence on expirationday effects using realized volatility: An intraday analysis for the Spanish stock exchange. Journal of Futures Markets: Futures, Options, and Other Derivative Products, 26(9), 923$938 \mathrm{https}: / /$ doi.org/10.1002/fut.20220

Kan, A.C.N. (2001). Expiration-day effect: Evidence from high-frequency data in the Hong Kong stock market. Applied Financial Economics, 11, 107-118. https://doi. org/10.1080/09603100150210318

Karolyi, A. G (1996) Stock market volatility around expiration days in Japan. Journal of Derivatives, 4, 23-43. http://doi.org/ 10.3905/jod.1996.407969

Klemkosky, R. C. (1978). The impact of option expirations on stock prices. Journal of Financial and Quantitative Analysis, 507518. http://doi.org/10.2307/2330155

Lu, X., \& Gao, H. (2016). The day of the week effect in Chinese stock market. The Journal of Asian Finance, Economics and Business, 3(3), 17-26. https://doi.org/10.13106/jafeb.2016. vol3.no3.17

Day, T. E., \& Lewis, C. M. (1988). The behavior of the volatility implicit in the prices of stock index options. Journal of Financial Economics, 22(1), 103-122.

Mahalwala, R. (2016). A study of expiration-day effects of index derivatives trading in India. Metamorphosis, 15(1), 10-19. https://doi.org/10.1177/0972622516629029

Narang, S., \& Vij, M. (2013). Long-term effects of expiration of derivatives on Indian spot volatility. International Scholarly Research Notices, 2013. https://doi.org/10.1155/2013/718538

Nelson, D. B. (1991). Conditional heteroskedasticity in asset returns: A new approach. Econometrica: Journal of the Econometric Society, 347-370. https://www.jstor.org/stable/2938260
Nguyen, A. T. K., \& Truong, L. D. (2020). The impact of index future introduction on spot market returns and trading volume: Evidence from Ho Chi Minh stock exchange. The Journal of Asian Finance, Economics and Business (JAFEB), 7(8), 51-59. https://doi.org/10.13106/jafeb.2020.vol7.no8.051

Nguyen, C. T., \& Nguyen, M. H. (2019). Modelling stock price volatility: Empirical evidence from the Ho Chi Minh City stock exchange in Vietnam. The Journal of Asian Finance, Economics and Business (JAFEB), 6(3), 19-26. https://doi. org/10.13106/jafeb.2020.vol7.no8.051

Officer, D., \& Trennepohl, G. (1981). Price behavior of corporate equities near option expiration dates. Financial Management, 10, 75-80. https://www.jstor.org/stable/3665051

Pope, P. F., \& Yadav, P. K. (1992). The impact of option expiration on underlying stocks: The UK evidence. Journal of Business Finance and Accounting, 19(3). https://doi. org/10.1111/j.1468-5957.1992.tb00628.x

Stoll, H.R., \& Whaley, R.E. (1987). Program trading and expirationday effects. Financial Analysts Journal, 43, 16-28. https://doi. org/10.2469/faj.v43.n2.16

Stoll, H.R., Whaley, R. E. (1990). The dynamics of stock index and stock index futures returns. Journal of Financial and Quantitative Analysis, 25, 441-67. https://www.jstor.org/ stable/2331010

Stoll, H.R., \& Whaley, R.E. (1991). Expiration day effect: what has changed. Financial Analysts Journal, 47, 58-72. https://doi. org/10.2469/faj.v47.n1.58

Thenmozhi, M., \& Thomas, M. S. (2004). Impact of index derivatives on S\&P CNX nifty volatility: Information efficiency and expiration effects. The ICFAI Journal of Applied Finance, 10(9), 36-55.

Vipul (2005). Futures and options expiration-day effects: The Indian evidence. The Journal of Futures Markets, 25, 1045-65. http://doi.org/ 10.1002/fut.20178

Wats, S. (2017). Expiration Day Impact on the Indian Spot Market Volatility. NMIMS Management Review, 33, 88-97. 